ISSN : 2580-3220, E-ISSN : 2580-4588

J. Mandiri., Vol. 4, No. 2, Desember 2020 (160 - 170)

C2018 Lembaga Kajian Demokrasi

dan Pemberdayaan Masyarakat (LKD-PM)

DOI : https://doi.org/10.33753/mandiri.v4i2.132

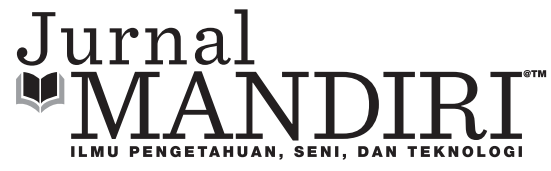

\title{
Strategi Pemasaran E-commerce Untuk Meningkatkan Volume Penjualan (Studi Kasus UMKM di Kota Tangerang Selatan)
}

\author{
Sam Cay \\ Fakultas Ekonomi, Universitas Pamulang \\ dosen02207@unpam.ac.id \\ Jeni Irnawati \\ Fakultas Ekonomi, Universitas Pamulang \\ dosen02228@unpam.ac.id
}

\begin{abstract}
Abstrak
Tujuan penelitian ini untuk mengetahui strategi pemasaran yang dilakukan oleh parapelaku UMKM, khususnya di Kota Tangerang Selatan. Salah satu strategi pemasaran yang dilakukan adalah melalui E-commerce. E-commerce merupakan proses pembelian maupun penjualan produk secara elektronik. E-commerce sendiri semakin berkembang beberapa tahun belakangan ini dan secara perlahan menggantikan toko tradisional. Teknik analisis data yang digunakan dalam penelitian ini adalah metode deskriptif kualitatif yaitu deskriptif tidak memberikan perlakuan, manipulasi atau pengubah pada variabel-variabel yang diteliti, melainkan menggambarkan suatu kondisi yang apa adanya. Satu-satunya perlakuan yang diberikan hanyalah penelitian itu sendiri, yang dilakukan melalui observasi, wawancara, dan dokumentasi. Hasil penelitian menunjukkan para UMKM khususnya di Kota Tangerang Selatan menggunakan strategi pemasaran melalui E-commerce. Dengan begitu penjualan produk dan skill mereka dapat bertambah.
\end{abstract}

Kata Kunci : Strategi Pemasaran, E-commerce, UMKM

\begin{abstract}
The purpose this study to determine the marketing strategies carried out by MSME actors, especially in the city of South Tangerang. One of the marketing strategies is through E-commerce. E-commerce is the process of buying and selling products electronically. E-Commerce itself has grown in recent years and is slowly replacing traditional shops. The data analysis method used in this research is descriptive qualitative, namely descriptive does not provide treatment, manipulation or modifying the variables studied, but describes a condition as it is. The only treatment given is the research itself, which is carried out through observation, interviews, and documentation. The results showed that MSMEs, especially in the city of South Tangerang, use marketing strategies through E-commerce. So, that their product sales and skills can increase.
\end{abstract}

Keywords : Marketing Strategy, E-commerce, MSMEs

\section{PENDAHULUAN}

Perkembangan teknologi yang cepat membuat para pelaku usaha juga harus cepat untuk menyesuaikan dengan perubahan tersebut. Salah satu bentuk teknologi adalah media sosial. Indo- nesia merupakan salah satu negara dengan tingkat pengguna media sosial terbesar di dunia.

Berdasarkan laporan terbaru We Are Social, pada 2020 ada 175,4 juta pengguna internet di Indonesia. Apabila dibandingkan dengan tahun 
sebelumnya, maka ada kenaikan $17 \%$ atau 25 juta pengguna internet di negeri ini. Dalam laporan tersebut juga diketahui bahwa saat ini masyarakat Indonesia yang memiliki ponsel sebanyak 338,2 juta.

Begitu juga dengan data yang tak kalah menariknya, di mana ada 160 juta pengguna aktif media sosial (medsos). Bila dibandingkan pada 2019, maka pada tahun ini ada peningkatan 10 juta yang aktif di medsos. Sehingga saat ini banyak sekali Usaha Mikro, Kecil, dan Menengah (UMKM) yang telah memanfaatkan media sosial dalam pemasaran.

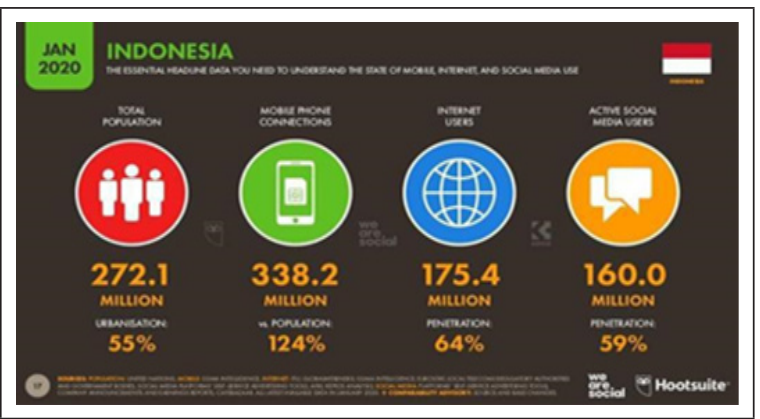

Gambar 1. Data Pengguna Internet di Indonesia

Indonesia juga merupakan salah satu negara dengan jumlah sektor UMKM terbesar. Kementerian Koperasi dan Usaha Kecil dan Menengah Republik Indonesia (Kemenkop/ UKM RI) mencatat ada 59,2 juta atau berkisar 8\% dari pelaku UMKM sudah memanfaatkan platform online dalam memasarkan produknya. Selanjutnya, berdasarkan data Dinas Koperasi dan UKM Provisinsi Banten pada 2018, di Kota Tangerang Selatan terdapat 9.582 pelaku UMKM.

Pemasaran adalah salah satu bagian penting dalam menjalankan suatu usaha. Perlu adanya pengelolaan yang baik agar usaha tersebut dapat tumbuh dan berkembang lebih baik sehingga mampu bersaing dengan para pesaingnya. Salah satu elemen yang penting dalam pemasaran adalah strategi pemasaran dan bauran pemasaran (marketing mix). Strategi pemasaran diperlukan agar segmen pasar, penentuan pasar sasaran, dan penentuan posisi pasar dapat dengan tepat dipilih.

Website dan media sosial telah memberikan banyak peluang bagi para pelaku UMKM untuk dapat mengembangkan pasar mereka terutama dalam hal promosi untuk menarik sasaran pasar yang mereka tuju. Adapun hal lainnya yang membuat para pelaku UMKM memasarkan produk dan jasa mereka melalui website dan media sosial adalah karena tingkat entry barriers yang rendah sehingga mereka dapat dengan mudah memasarkan produk dan jasa mereka pada website dan media sosial tersebut (Oztamur dan Karakadilar, 2014).

Penelitian yang dilakukan oleh Knight (2000) menunjukkan bahwa globalisasi memiliki dampak dan tekanan yang signifikan bagi sektor UMKM. Dengan demikian para pelaku UMKM tersebut harus dapat menerapkan penggunaan teknologi yang tepat guna dan sesuai bagi usaha yang mereka jalankan. Tujuannya agar mereka mampu bersaing secara efektif atau mengeluarkan produk baru mereka yang lebih memuaskan kebutuhan konsumen mereka dibandingkan dengan produk sejenis di pasar.

Berdasarkan uraian tersebut maka rumusan masalah yang diangkat dalam penelitian ini adalah untuk mengeksplorasi serta menganalisis strategi pemasaran dan bauran pemasaran yang digunakan oleh para pelaku UMKM di Kota Tangerang Selatan dalam era digital. Khususnya, dengan banyaknya jumlah pengguna media sosial di Indonesia.

Selanjutnya, dalam penelitian ini definisi Usaha Mikro, Kecil, dan Menengah merujuk pada Undang-Undang Nomor 20 Tahun 2008 Tentang Usaha Mikro, Kecil, dan Menengah adalah usaha produktif milik orang perorangan dan/atau badan usaha perorangan yang memenuhi kriteria Usaha Mikro. Adapun kriteria kelompok usaha mikro yaitu (a) Memiliki kekayaan bersih paling banyak Rp50.000.000,00 (lima puluh juta rupiah) tidak termasuk tanah dan bangunan tempat usaha; atau (b) Memiliki hasil penjualan tahunan paling banyak Rp300.000.000,00 (tiga ratus juta rupiah).

Usaha Kecil adalah usaha ekonomi produktif yang berdiri sendiri, yang dilakukan oleh orang perorangan atau badan usaha yang bukan merupakan anak perusahaan atau bukan cabang perusahaan yang dimiliki, dikuasai, atau menjadi bagian baik langsung maupun tidak langsung dari Usaha Menengah atau Usaha Besar yang memenuhi kriteria Usaha Kecil. Kriteria 
kelompok Usaha Kecil yaitu (a) Memiliki kekayaan bersih lebih dari Rp50.000.000,00 (lima puluh juta rupiah) sampai dengan paling banyak Rp500.000.000,00 (lima ratus juta rupiah) tidak termasuk tanah dan bangunan tempat usaha; atau (b) Memiliki hasil penjualan tahunan lebih dari Rp300.000.000,00 (tiga ratus juta rupiah) sampai dengan paling banyak Rp2.500.000.000,00 (dua miliar lima ratus juta rupiah).

Kemudian Usaha Menengah adalah usaha ekonomi produktif yang berdiri sendiri, yang dilakukan oleh orang perorangan atau badan usaha yang bukan merupakan anak perusahaan atau cabang perusahaan yang dimiliki, dikuasai, atau menjadi bagian baik langsung maupun tidak langsung dengan Usaha Kecil atau Usaha Besar dengan jumlah kekayaan bersih atau hasil penjualan tahunan. Kriteria kelompok Usaha Menengah yaitu (a) Memiliki kekayaan bersih lebih dari Rp500.000.000,00 (lima ratus juta rupiah) sampai dengan paling banyak Rp10.000.000.000,00 (sepuluh miliar rupiah) tidak termasuk tanah dan bangunan tempat usaha; atau (b) Memiliki hasil penjualan tahunan lebih dari Rp2.500.000.000,00 (dua miliar lima ratus juta rupiah) sampai dengan paling banyak Rp50.000.000.000,00 (lima puluh miliar rupiah).

Sedangkan menuruthasilstudiyang dilakukan oleh Lembaga Pengembangan Perbankan Indonesia dengan Bank Indonesia di tahun 2015, terdapat beberapa karakteristik yang khas dari UMKM ini. Karakteristik khas tersebut meliputi kualitas produk atau jasa belum terstandar, hal ini disebabkan karena sebagian UMKM memiliki kemampuan teknologi yang belum memadai serta sebagian besar produk atau jasa yang dihasilkan masih handmade. Desain produk yang terbatas, hal ini dikarenakan terbatasnya pengetahuan dan pengalaman UMKM terhadap produk atau jasa mereka. Mayoritas UMKM bekerja sesuai dengan permintaan pelanggannya sehingga belum berani untuk mencoba berkreasi dengan desain baru. Jenis produk atau jasa yang dihasilkan masih terbatas, umumnya UMKM hanya memproduksi beberapa jenis produk atau jasa saja. Apabila terdapat permintaan untuk model baru, mereka cenderung mengalami kesulitan untuk memenuhi permintaan tersebut, jikapun diterima, maka akan memerlukan waktu yang lebih lama untuk memenuhi permintaan tersebut.

Karakteristik khas selanjutnya dari UMKM adalah kapasitas dan daftar harga produk yang terbatas, UMKM cenderung mengalami kesulitan dalam hal menetapkan kapasitas produksi dan harga bagi produk atau jasa mereka. Bahan baku kurang terstandar, hal ini dipengaruhi oleh sumber bahan baku yang berasal dari berbagai sumber yang berbeda-beda, maka hal ini tentu akan juga berpengaruh pada hasil produk yang dihasilkan. Keberlangsungan produk yang tidak terjamin dan kurang sempurna, hal ini dikarenakan umumnya produksi UMKM masih belum teratur sehingga akan berpengaruh pada produk yang dihasilkan juga masih terkesan apa adanya.

Pemasaran melibatkan banyak pihak dalam perusahaan. Oleh karena itu pemasaran merupakan prestasi kerja dalam suatu kegiatan usaha dengan mengalirnya suatu barang atau jasa dari produsen sampai ke konsumen. Menurut Hutama dan Subagio (2014: 3), pemasaran merupakan serangkaian kegiatan mulai dari proses dalam pembuatan, mengkomunikasikan mengenalkan dan menawarkan transaksi yang mempunyai nilai bagi konsumen, klien, partner, dan masyarakat pada umumnya. Sedangkan pemasaran jasa menurut Ali dalam Karnelis (2017: 721), pemasaran jasa merupakan proses sosial di mana individu dan kelompok mendapatkan apa yang mereka butuhkan dan inginkan dengan mempertukarkan jasa yang bernilai.

Menurut Sofjan Assauri (2013: 15), "strategi pemasaran adalah serangkaian tujuan dan sasaran, kebijakan dan aturan yang memberi arah kepada usaha-usaha pemasaran perusahaan dari waktu ke waktu, pada masing-masing tingkatan dan acuan serta alokasinya, terutama sebagai tanggapan perusahaan dalam menghadapi lingkungan dan keadaan persaingan yang selalu berubah".

Unsur-unsur utama persaingan dapat diklasifikasikan menjadi tiga unsur utama, yaitu Segmentasi (segmentation). Segmentasi pasar adalah kegiatan membagi-bagi pasar yang bersifat heterogen dari suatu produk ke dalam 
satuan-satuan pasar (segmen pasar) yang bersifat heterogen. Jadi, perusahaan membagi pasarnya ke dalam segmen-segmen pasar tertentu di mana masing-masing segmen tersebut bersifat homogen. Hal ini disebakan karena dalam kenyataannya banyak produk yang bersifat heterogen bagi seluruh pasar, atau produk tersebut hanya diperlukan oleh kelompok pasar tertentu saja. Homogenitas masing- masing segmen tersebut disebabkan oleh adanya perbedaan-perbedaan dalam kebiasaan membeli, cara penggunaan barang, kebutuhan pemakai, motif pembelian, tujuan pembelian, dan sebagainya. Jadi, segmentasi ini merupakan proses yang menyeluruh di mana perusahaan harus memperhatikan pembeli dari masing-masing segmen.

Unsur berikutnya adalah penentuan pasar sasaran (targeting). Tahap ini adalah mengevaluasi beragam segmen dan memutuskan berapa banyak dan mana yang akan dibidik. Dalam membidik konsumen, pemasar harus dapat membedakan pasarnya antara pasar jangka pendek dan pasar masa depan serta pasar primer dan pasar sekunder.

Sedangkan unsur yang terakhir adalah penentuan posisi tawaran (positioning). Positioning merupakan konsep psikologis yang terkait dengan bagaimana pelanggan yang ada atau calon pelanggan dapat menerima perusahaan tersebut dan produknya dibandingkan dengan perusahaan lain. Penentuan posisi merupakan tindakan untuk merancang penawaran dan citra perusahaan agar menempati suatu posisi kompetitif yang berarti dan berbeda. Dalam memahami bagaimana sebenarnya penentuan posisi pasar ini, perlu diperhatikan beberapa aspek terkait seperti atribut diferensiasi utama yang dapat digunakan perusahaan serta konsep penentuan posisi.

Hal yang penting pula diperhatikan dalam pemasaran adalah bauran pemasaran. Menurut Kotler dan Armstrong (2014), ada empat elemen dalam bauran pemasaran yaitu produk, harga, promosi, dan tempat. Produk adalah kombinasi dari produk dan jasa yang ditawarkan oleh perusahaan ke pasar sasaran. Hal yang terkait dengan produk antara lain adalah variasi produk atau jasa, kualitas, desain, fitur, nama merk dari produk atau jasa, kemasan serta layanan. Harga adalah sejumlah uang yang dibayarkan oleh konsumen untuk memperoleh produk atau jasa. Beberapa hal yang terkait dengan harga adalah diskon, waktu pembayaran, syarat kredit, dan daftar harga.

Selanjutnya promosi adalah aktivitas perusahaan yang mengkomunikasikan kelebihan dan manfaat produk atau jasa dengan tujuan untuk mengajak pasar sasaran membeli produk atau jasa tersebut. Beberapa hal yang terkait dengan promosi adalah iklan, promo penjualan, hubungan masyarakat, dan personal selling. Terakhir, tempat yaitu seluruh aktivitas yang dilakukan oleh perusahaan yang membuat produk atau jasanya tersedia di pasar sesuai dengan pasar sasaran perusahaan tersebut. Beberapa hal yang terkait dengan tempat adalah jaringan distribusi, jangkauan pemasaran, lokasi, persediaan, logistik, dan transportasi.

Dewasa ini dikenal pula strategi pemasaran dengan menggunakan media sosial (e-commerce). Media sosial memang sangat diminati UMKM untuk mengembangan bisnisnya. Media sosial mempunyai pengaruh yang sangat besar, di mana masyarakat lebih cepat menerima informasi lewat internet. Dengan akses yang mudah dan cepat hal ini dimanfaatkan oleh para pelaku UMKM untuk lebih berani mempromosikan produk produknya karena jaringan internet yang sangat luas dan tidak ada batasan waktu dan wilayah sehingga menjadi media pemasaran yang efektif. Oleh karena itu media sosial dapat dijadikan sebagai alat untuk mengembangkan usaha terutama UMKM dalam mempromosikan usahanya. Saat ini banyak sosial media yang dapat digunakan untuk promosi. Bahkan, saat ini banyak sekali pegiat media sosial yang menjadikan media online sebagai ladang untuk memperoleh keuntungan bagi mereka dalam berjualan.

E-commerce (Elektronik Commerce) atau dalam bahasa Indonesia perdagangan secara elektronik adalah aktivitas penyebaran, penjualan, pembelian, dan pemasaran produk (barang dan jasa) dengan memanfaatkan jaringan telekomunikasi seperti internet, televisi, atau jaringan 
komputer lainnya. Secara sederhana e-commerce adalah proses pembelian maupun penjualan produk secara elektronik. E-Commerce sendiri semakin berkembang beberapa tahun belakangan ini. Bahkan, secara perlahan mulai menggantikan toko tradisional (offline).

Beberapa jenis e-commerce yang paling sering digunakan, antara lain e-commerce consumer to consumer (C2C). Jenis e-commerce $\mathrm{C} 2 \mathrm{C}$ ini dilakukan antara konsumen dengan konsumen. Misalnya, konsumen dari suatu produsen akan menjual kembali produk ke konsumen lainnya. Kalau Anda sering menggunakan Tokopedia, Bukalapak, OLX, dan sejenisnya, maka inilah yang dinamakan $\mathrm{B} 2 \mathrm{C}$ e-commerce.

Kemudian e-commerce business to business (B2B). Jenis bisnis B2B ini dilakukan oleh orang atau pihak yang saling berkepentingan dalam menjalankan bisnis, di mana keduanya saling mengenal dan mengetahui proses bisnis yang mereka lakukan. Biasanya, jenis B2B dilakukan secara berkelanjutan karena kedua belah pihak saling mendapatkan keuntungan dan adanya kepercayaan satu sama lain. Contoh dari bisnis B2B adalah ketika dua perusahaan mengadakan transaksi jual beli secara online, begitu juga dengan pembayaran yang tersedia menggunakan kartu kredit.

Jenis e-commerce lainnya yakni e-commerce consumer to business (C2B). Jenis $\mathrm{C} 2 \mathrm{~B}$ adalah bisnis antara konsumen dan produsen. Bisnis tersebut dilakukan oleh konsumen kepada para produsen yang menjual produk atau jasa. Sebagai contoh, konsumen akan memberitahukan detail produk atau jasa yang diinginkan secara online kepada para produsen. Nantinya, produsen yang mengetahui permintaan tersebut akan menawarkan produk atau jasa yang diinginkan konsumen.

Sedangkan jenis yang selanjutnya yaitu e-commerce business to consumer (B2C). Jenis e-commerce $\mathrm{B} 2 \mathrm{C}$ adalah dilakukan oleh pelaku bisnis dan konsumen. Transaksi e-commerce ini terjadi layaknya jual-beli biasa. Konsumen mendapatkan penawaran produk dan melakukan pembelian secara online. Sebagai contoh, produsen menjual produk ke konsumen secara online. Di sini, pihak produsen akan menjalankan bisnis dengan memasarkan produknya ke konsumen tanpa adanya feedback dari konsumen untuk melakukan bisnis kembali. Artinya, produsen hanya memasarkan produk atau jasa, sementara pihak konsumen hanya sebagai pembeli atau pemakai.

\section{METODE}

Penelitian ini merupakan jenis penelitian deskriptif kualitatif yang diuraikan dengan katakata menurut pendapat subjek penelitian. Metode penentuan lokasi penelitian menggunakan metode purposive area, yaitu pemilihan tempat penelitian yang disesuaikan dengan tujuan penelitian. Adapun lokasi penelitian yang ditetapkan oleh peneliti yaitu UMKM di Kota Tangerang Selatan.

Selanjutnya metode penentuan informan penelitian menggunakan metode purposive sampling. Adapun informan utama dalam penelitian ini adalah para pelaku usaha UMKM. Jenis dan sumber data berupa data primer dan data sekunder. Adapun data primer dalam penelitian ini yaitu data yang diperoleh secara langsung dari subjek atau para pelaku UMKM di Kota Tangerang Selatan melalui wawancara dengan subjek/narasumber yang berkaitan dengan strategi pemasaran yang digunakan dan data sekunder berupa dokumen-dokumen, seperti data jumlah karyawan, kegiatan strategi pemasaran yang dilakukan UMKM, dan profil UMKM di Kota Tangerang Selatan.

Metode pengumpulan data menggunakan metode wawancara dan dokumentasi. Dalam metode wawancara dalam penelitian ini dilakukan terhadap pemilik UMKM. Selain itu wawancara dilakukan terhadap informan tambahan yang merupakan karyawan. Adapun metode dokumentasi berupa data-data tertulis atau dokumen yang berkaitan dengan data jumlah karyawan, kegiatan strategi pemasaran yang dilakukan UMKM, dan profil UMKM di Kota Tangerang Selatan. Analisis data dilakukan dengan cara reduksi data, display data, dan penarikan kesimpulan. Penelitian ini dilakukan selama enam bulan yaitu dari Maret 2020 hingga Agustus 2020. 


\section{HASIL dan PEMBAHASAN}

Penelitian ini menggunakan metode penelitian kualitatif dengan pendekatan deskriptif. Peneliti menggunakan pendekatan deskriptif di mana berusaha meneliti sebuah fenomena yang terjadi dengan cara memaparkan berupa gambaran tentang suatu kejadian yang diamati oleh peneliti secara jelas, tanpa menggunakan perhitungan statistik. Dengan teknik tersebut peneliti berusaha mendapatkan informasi terkait dengan bagaimana pengaruh media sosial terhadap pengembangan UMKM di Kota Tangerang Selatan.

Berdasarkan hasil penelitian yang telah dilakukan, dengan melakukan wawancara kepada enam pelaku UMKM di Kota Tangerang Selatan maka dapat diketahui bahwa strategi pemasaran yang diterapkan oleh pelaku UMKM di Kota Tangerang Selatan antara lain strategi produk, strategi harga, strategi tempat, dan strategi promosi. Produk yang dikembangkan UMKM di Tangerang Selatan bervariatif.

Adapaun hasil wawancara yang telah dilakukan kepada responden sebagai berikut :

\section{Galeri Geulis}

Galeri Geulis merupakan usaha yang dimiliki oleh Jeni Andriani yang bergerak di bidang anyaman dan scraft dengan tujuan untuk mengangkat budaya lokal yang diambil dari Tasikmalaya. Galeri Geulis sudah berjalan kurang lebih dua tahun. Melihat peluang yang ada, Jeni mencoba untuk membuat lebih menarik macammacam anyaman mulai dari tas, dompet hingga merambah ke masker yang dibuat lebih menarik.

Saat ini strategi pemasaran yang dilakukan oleh Ibu Jeni melalui offline dan online. Untuk offline sendiri Galeri Geulis memiliki toko di Pondok Aren dan juga bergabung dengan rumah makan yang ada di daerah Vila Dago untuk memajang hasil karya dari produknya. Sedangkan untuk online, Jeni memanfaatkan grup WhatsAps, Facebook, dan Instagram. Selain itu Jeni juga membuka kesempatan untuk para reseller yang ingin menjual produknya.

Adapun keuntungan yang dirasakan setelah menjual melalui e-commerce adalah meningkat- nya penjualan produk di mana hasil penjualan bisa menjangkau lebih luas. Kemudian Jeni juga memanfaatkan brand community yaitu dengan cara bergabung dengan komunitas Tangsel Berkibar, yaitu suatu komunitas pelaku UMKM. Jeni sudah bergabung dengan komunitas tersebut kurang lebih setahun. Manfaat yang dirasakan setelah bergabung adalah adanya info-info mengenai bazar, sharing ilmu, pelatihan melalui webinar untuk menanmbah pengetahuan, dan skill serta adanya promosi-promosi terhadap produk yang dijual. Dengan bergabung di komunitas tentunya peningkatan hasil penjualan juga dirasakan karena salah satu program dalam komunitas adalah adanya gerakan berbelanja ke sesama pelaku UMKM.

\section{Minyak Kelapa V-CO}

Sebelum memulai usaha minyak kelapa V-CO, Novia sudah menjalankan beberapa usaha lainnya. Namun saat ini ia bersama suami sedang fokus untuk mengembangkan usaha minyak kelapa V-CO. Awal mula usaha ini dijalankan karena melihat peluang di mana bahan bakunya banyak di mana saat pengiriman kelapa ke daerahnya, ternyata banyak kelapa yang sudah tua dan tidak bisa dijual sebagai santan. Karena sayang jika dibuang begitu saja maka akhirnya Novia mencoba membuat olahan dari kelapa tersebut.

Menurut Novia, usaha yang dijalankan saat ini susah-susah gampang. Artinya setiap orang bisa membuat minyak kelapa, namun tidak semua orang mau membuatkan karena prosesnya yang panjang dan butuh kesabaran dalam pengelolaannya. Produk ini bisa dipergunakan untuk kesehatan maupun perawatan wajah karena pengelolaannya yang sudah terjamin higienis dan asli dari kelapa.

Saat ini strategi pemasaran yang dilakukan Novia dalam meningkatkan penjualan produknya adalah dengan berjualan melalui e-commerce yaitu WhatsApp, Facebook, dan Instagram. Selain itu Novia juga sudah lebih dari satu tahun bergabung dengan komunitas IKM (Ikatan Keluarga Minang), di mana anggota tersebut berisikan para pedagang minang. Manfaat dari komunitas tersebut adalah informasi mengenai berbagai bazar- 
bazar yang akan dilaksanakan sehingga Novia bisa ikut berjualan dalam kegiatan bazar tersebut.

\section{Keripik Singkong Uni Ambo}

Afridayani merupakan pemilik usaha Keripik Singkong Uni Ambo yang sudah berjalan lebih dari lima tahun. Usaha tersebut mulai berjalan dan berkembang dengan lancar. Hal ini terbukti dari proses pengepakan di mana mulanya pengepakkan dengan cara manual yaitu dengan bantuan lilin sampai dengan proses pengepakan dengan mesin. Dengan demikian proses pengepakan lebih bagus dan baik.

Saat ini produk Keripik Singkong Uni Ambo sudah mendapatkan izin dari dinas kesehatan dan pangan. Dengan latarbelakang orang Sumatera Barat yang memiliki darah pedagang dan belajar autodidak. Usaha tersebut bertujuan untuk menambah penghasilan keluarga dan bisa membantu para tetangga. Sebab pada saat produksi meningkat maka Afridayani akan menggunakan jasa para tetangganya dalam melakukan proses pengepakan. Selain itu ia juga merasa punya kepuasan tersendiri apabila mendapatkan penghasilan dari berdagang karena sesuai yang diajarkan Rasullullah SAW bahwa 99\% penghasilan dari berdagang itu halal.

Strategi pemasaran yang dilakukan oleh Afridayani adalah offline dan online. Untu yang offline, ia bekerjasama dengan salah satu minimarket yaitu dengan menitipkan produknya di tempat tersebut. Sedangkan untuk yang online, ia memanfaatkan grup WhatsApp, Facebook, Instagram, dan membuka peluang bagi para reseller untuk menjual produk Keripik Singkong Uni Ambo. Selain itu Afridayani juga bergabung ke dalam komunitas pelaku UMKM, yaitu Komunitas Tangsel Berkibar yang juga diikuti oleh Jeni Andriani. Ia pun telah merasakan manfaat yang sama dengana mengikuti komunitas tersebut, sebagaimana yang telah dirasakan oleh Jeni Andriani. Dengan penjualan melalui e-commerce dan bergabung dengan komunitas, Afridayani sangat merasakan adanya peningkatan penjualan produknya.

\section{Dapur Mami Anjani dan Galeri Mami Anjani}

Nara sumber keempat bergerak di bidang jasa dekorasi bunga beserta produk berupa bungabunga dan kuliner masakan daerah yang diinovasi sehingga cocok dengan selera orang sini. Pemiliknya adalah Rissa Hanny, yang memulai usaha kulinernya sejak 2013 dengan pembukaan Rumah Makan Padang di daerah Blok M. Hingga 2018, Rissa telah memiliki enam cabang. Namun pada 2019 saat memiliki anak bayi, ia memutuskan untuk menutup semua usahanya karena tidak ada waktu untuk mengelola usaha tersebut.

Rugi? Pastinya iya. Karena semua peralatan yang dibeli tidak terpakai dan juga karena faktor lainnya. Akhirnya pada 2019, Rissa memutuskan untuk membuka usaha di rumah yang diberi nama Dapur Mama Anjani. Karena waktu dan tenaga yang sangat banyak dibutuhkan di bidang kuliner, ia memutuskan untuk mengubah sistem dari yang semula menyetok makanan kemudian berubah menjadi sesuai pesanan dari pelanggan. Ia juga mencoba hal lain sesuai hobinya yaitu mengelola barang-barang tidak terpakai menjadi hiasan dinding. Ternyata ada beberapa yang tertarik dan akhirnya ia pun mencoba menggali lebih dalam pangsa pasar yang akhirnya terbentuk.

Strategi pemasaran yang digunakan Rissa adalah dengan mengikuti pameran-pameran serta membuka peluang para reseller. Hingga saat ini ia telah mendapatkan reseller antara lain di Kalimantan, Medan, dan Riau. Pemasaran melalui e-commerce juga dijalankannya. Melalui online, ia telah merasakan kemudahan dalam me-manage semua transaksi penjualan. Selain itu adanya fleksibel waktu yang sangat ia rasakan.

E-commerce yang digunakan adalah Lazada, Facebook, WhatsApp, dan Instagram yang dimulai sejak 2019. Ia merasakan penjualan meningkat sehingga berpengaruh pada omset yang diterimanya. Selain itu Rissa juga sudah dua tahun bergabung dengan beberapa komunitas seperti Komunitas Kuliner Indonesia, Komunitas IWAPI (Ikatan Wanita Pengusaha Indonesia) dan beberapa komunitas lain. Ia menegaskan, jika tidak bergabung dengan komunitas, maka akan sulit mendapatkan informasi-informasi mengenai UMKM. 


\section{Minyak Kelapa MCC}

Usaha minyak kelapa MCC berdiri pada 2017. Anggi bergabung dengan komunitas yang membahas tentang diet yang menggunakan minyak kelapa. Dari situ ia melihat peluang untuk membuat sendiri yang kemudian dipasarkan. Sejak bergabung dengan komunitas, Anggi sangat merasakan manfaatnya. Karena dari komunitaslah banyak reseller-reseller yang bergabung menjual produk tersebut. Setelah mencoba memasarkan melalui komunitas tersebut ternyata banyak peminatnya, yang akhirnya ia putuskan untuk fokus menjalankannya.

Saat ini produk sudah dijual melalui e-commerce seperti Tokopedia, Bukalapak, Instagram, Facebook, dan WhatsApp. Setelah melakukan penjualan melalui e-commerce, Anggi merasakan adanya peningkatan. Karena biasanya produk hanya dibeli oleh rekan-rekannya dan di tempat ia tinggal. Namun dengan adanya penjualan melalui e-commerce, produknya bisa dijual ke seluruh Indonesia. Apabila penjualan menurun maka ia mencoba memasarkan melalui endorse para selebgram. Kemudian iklan di e-commerce, dengan menggunakan strategi harga yang harus bersaing bahkan lebih murah dibanding kompetitor.

\section{Marenta Tangsel}

Berawal dari ketertarikan untuk menjadi reseller Marenta, akhirnya Nur Rachma Wahidah memutuskan untuk menjadi agen Marenta di Kota Tangerang Selatan. Produk yang ditawarkan dari usaha kuliner ini antara lain Cireng Banjir, Batagor Banjir, Cuanki Banjir, dan Seblak Banjir. Rachma dengan berani resign dari pekerjaan dan memulai usaha tersebut.

Strategi penjualan yang dilakukan Rachma yaitu dengan cara offline seperti mengikuti bazar yang diselenggarakan di Kota Tangerang Selatan. Ia juga bergabung dengan Komunitas UMKM Tangsel Berkibar. Selain itu Rachma juga berjualan dengan memanfaatkan media online seperti Instagram, Facebook, dan Grup WhatsApp. Bahkan ia pun memanfaatkan platform e-commerce seperti Shopee, Tokopedia, dan Lazada untuk meningkatkan volume penjualannya. Selain itu Rachma juga membuka peluang untuk drophip produk tersebut.

Berdasarkan data Dinas Koperasi dan UKM Provisinsi Banten tahun 2018, di Kota Tangerang Selatan terdapat 9.582 pelaku UMKM. Beberapa UMKM yang ada di Kota Tangerang Selatan per kecamatan dapat dilihat pada grafik berikut. Di Kota Tangerang Selatan terdapat 23 pelaku UMKM yang bergerak di berbagai bidang antara lain kuliner, kerajinan, konveksi, dan jasa. Namun dari UMKM tersebut baru 11 yang menggunakan media sosial untuk pemasaran produknya. Responden tersebut merupakan pelaku UMKM yang sudah menggunakan dan memanfaatkan media sosial untuk memasarkan produk-produknya. Dari hasil wawancara tersebut seluruhnya dapat diolah menjadi data yang berguna bagi penelitian selanjutnya.

Berikut gambar berupa grafik jumlah UMKM per-kecamatan yang ada di Kota Tangerang Selatan:

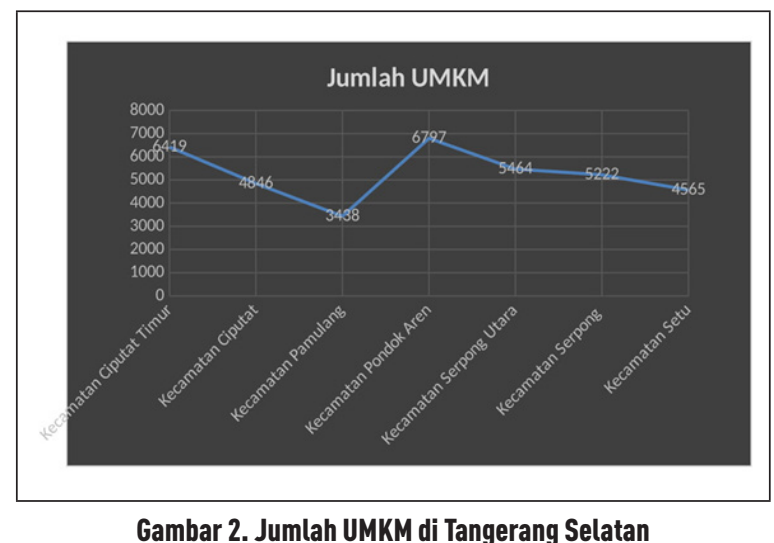

Sumber: Dinas Koperasi dan UMKM Kota Tangerang Selatan (Data diolah, 2020)

Strategi pemasaran yang dilakukan oleh para penggiat UMKM tergolong unik. Hal ini sesuai dengan hasil analisis segmentasi pasar, penentuan pasar sasaran, posisi pasar, dan diferensiasi yang diterapkan. Penggiat UMKM sepakat bahwa kondisi persaingan saat ini semakin ketat sehingga mereka harus menggunakan strategi pemasaran yang tepat. Secara umum mereka memanfaatkan media sosial dan komunitas UMKM untuk meningkatkan volume penjualan. Selain itu pelaku UMKM di Kota Tangerang Selatan juga mencari reseller agar bisa ikut mempromosikan dan men- 
jual produk mereka.

Dari aspek bauran pemasaran, meskipun produk yang dijual relatif sama dengan para pesaing, namun karena mengedepankan nilai tambah dan diferensiasi, maka mereka dapat memberikan produk yang tepat. Selain itu harga yang layak dan bersaing, pemilihan saluran distribusi yang sesuai, serta pemilihan media promosi yang efektif bagi para pelanggan. Dengan demikian kepuasan dan loyalitas pelanggan dapat tercapai.

Penggunaan teknologi dalam seperti website dan media sosial telah banyak digunakan. Terutama pada industri kuliner, anyaman, dan produk kesehatan. Bagi para penggiat UMKM, peran dari website dan media sosial merupakan sarana bagi mereka untuk menjalin hubungan dengan para pelanggan, mengetahui pendapat, dan saran pelanggan terhadap produk mereka serta sebagai media promosi yang dianggap efektif. Bahkan dapat melakukan pengembangan produk sesuai dengan keinginan pasar.

Hal ini mendukung penelitian sebelumnya yang dilakukan Mohd Irwan Dahnil et al (2014). Mereka melakukan penelitian kepada usaha kecil dan menengah di Malaysia. Berdasarkan studi tersebut para pelaku usaha kecil dan menengah yang menggunakan media sosial sebagai bagian dari aktivitas pemasaran seperti strategi komunikasi pemasaran. Mereka menilai media sosial adalah salah satu jaringan yang menjanjikan untuk membangun komunikasi bisnis dengan para pelanggan.

Penelitian lainnya dilakukan oleh Nory Jones et al (2015) dengan objek penelitian pada UMKM. Mereka menemukan bahwa peran dari media sosial bagi pelaku UMKM yaitu (1) meningkatkan pengenalan dan rasa ingin tahu konsumen, (2) meningkatkan hubungan baik dengan konsumen, (3) dapat meningkatkan jumlah konsumen baru, (4) meningkatkan kemampuan untuk menjangkau konsumen dalam skala global, dan (5) menambah jalur promosi bagi bisnis lokal untuk meningkatkan citra UMKM.

Sementara itu Damian Ryan (2014) juga menyebutkan beberapa manfaat menjalin hubungan dekat dengan pelanggan, yakni: (1) mendapatkan update informasi dari pelanggan,
(2) meningkatkan reputasi profil media sosial perusahaan, (3) menambah sumber informasi selain dari media offline yang dapat digunakan sebagai studi pasar, (4) dapat mempengaruhi influencers untuk ikut pula mempengaruhi para followers-nya sehingga produk mereka mendapat citra yang baik dan positif.

\section{SIMPULAN}

Berdasarkan hasil penelitian dan pembahasan dapat disimpulkan bahwa UMKM di Kota Tangerang Selatan dalam strategi pemasarannya menerapkan atau menggunakan strategi bauran pemasaran atau yang lebih dikenal dengan istilah marketing mix. Dalam memasarkan produknya dilakukan melalui strategi produk, strategi harga, strategi tempat, dan strategi promosi.

Strategi produk yang dilakukan oleh UMKM di Kota Tangerang Selatan mengutamakan kualitas produk seperti dari segi bahan baku yang digunakan dan proses produksinya. Selain itu, dalam proses pengemasan produk lebih mempunyai ciri khas seperti pada usaha anyaman, di mana motif yang disediakan sangat beragam sehingga menarik minat para konsumen. Sedang usaha lainnya seperti makanan di mana menu yang disediakan beraneka ragam dan sesuai permintaan konsumen. Dengan demikian konsumen tidak bosan dengan menu yang itu saja dan bisa request sesuai dengan yang diinginkan. Penentuan harga yang dilakukan pelaku UMKM mengacu pada kesulitan proses produksi dan bahan baku yang digunakan agar tercapai harga yang tepat.

Kegiatan distribusi yang dilakukan oleh UMKM di KotaTangerang Selatan adalah distribusi langsung. Misalnya, dengan melakukan komunikasi pesanan secara langsung ke konsumen dan melayani penjualan langsung dari stok produk yang ada di galeri maupun di tempat usaha. Pelaku UMKM di Kota Tangerang Selatan juga sering mengikuti pameran, bazar ataupun eventevent tertentu. Selain itu, strategi promosi yang dilakukan yakni dengan penjualan perorangan seperti bertatapan langsung dengan konsumen, pengiklanan melalui kartu nama, dan media sosial seperti grup WhatsApp, Facebook, dan Instagram. 
Hal ini dilakukan agar dapat menjaring reseller untuk menjual produk tersebut serta menerapkan potongan harga dan promosi dari mulut ke mulut.

\section{PENGHARGAAN}

Puji syukur saya sampaikan kehadirat Allah SWT, yang telah memberikan rahmat dan kehendak-Nya sehingga terselesaikan penelitian ini. Selanjutnya ucapan terima kasih disampaikan kepada Dinas Koperasi dan UKM Kota Tangerang Selatan yang telah memberikan informasi mengenai UMKM yang ada di Kota Tangerang Selatan. Selain itu kami mengucapkan terima kasih pula kepada para nara sumber yang telah memberikan waktu untuk melakukan wawancara sehingga penelitian ini dapat terwujud.

\section{DAFTAR PUSTAKA}

Abdullah, Thamrin dan Francis Tantri. (2016). Manajemen Pemasaran. Depok: PT Raja Grafindo Persada

Amin Widjaja Tunggal. (2011). Pengantar Kecurangan Korporasi. Jakarta: Harvarindo.

Anjasmoro, Diki Putro dan M. Kholid Mawardi. (2017). Jurnal Administrasi Bisnis (JAB) Vol. 47 No. 2. "PERAN BRAND COMMUNITY DALAM MENCIPTAKAN BRAND IMAGE (Studi Kasus Pada Komunitas Vario Owner Club Malang)".

Assauri, Sofjan. (2013). Manajemen Pemasaran. Jakarta: Rajawali Pers.

Dewi Jayanti Mandasari, Joko Widodo, Sutrisno Djaja. (2019). Jurnal Pendidikan Ekonomi: Jurnal Ilmiah Ilmu Pendidikan, Ilmu Ekonomi, dan Ilmu Sosial Vol. 13 No. 1. "Strategi Pemasaran Usaha Mikro, Kecil dan Menengah Batik Magenda Tamanan Kabupaten Bondowoso".

Dimas Hendika Wibowo, Zainul Arifin, Sunarti. (2015). Jurnal Administrasi Bisnis (JAB), Vol. 29 No.1. "Analisis Strategi Pemasaran Untuk Meningkatkan Daya Saing UMKM".

https://wearesocial.com/blog/2020/01/digital2020-3-8-billion-people-use-social-media

Herlambang, Susatyo. (2014). Basic Marketing (Dasar-dasar Pemasaran) Cara Mudah Me- mahami Ilmu Pemasaran. Yogyakarta: Kdt.

Hutama, Cristanto Leona, Subagio. (2014). Analisa Pengaruh Dining Experience Terhadap Behavioral Intention dengan Customer Satisfaction sebagai Variabel Intervening. Jurnal Manajemen Pemasaran Petra, 2.

Karnelis. (2017). Pengaruh Bauran Pemasaran terhadap keputusan Konsumen menggunakan Jasa Hotel Kartika Langsa. Jurnal Manajemen dan Keuangan Sekolah Tinggi Ilmu Manajemen Pase, 6.

Kotler, dan Keller. (2012). Manajemen Pemasaran. Edisi 12. Jakarta: Erlangga.

Laroche, M. et al. (2013). To be or not to be in social media: How brand loyalty is affected by social media ?. International Journal of Information Management 33 ( ) Elsevier Ltd.

McAlexander, James H., John W. Schouten, and Harold F. Koenig, Building Brand Community, Journal of Marketing Vol. 66 (January 2002), 38-54.

Mursid, M. 2010. Manajemen Pemasaran (Edisi 1 Cetakan.6). Jakarta: Bumi Aksara.

Shendy Swastika Sari, Sri Nuringwahyu, Ratna Niken Hardati. (2020). Jurnal JIAGABI ISSN 2302 - 7150 Vol. 9, No. 1, Januari 2020, hal. 43-54. "Strategi Bisnis Usaha Mikro, Kecil dan Menengah Dalam Meningkatkan Penjualan".

Siska Maya. (2016). Journal of Applied Business and Economics Volume 2 Nomor 3. "Strategi Peningkatan Penjualan Usaha Kecil Menengah Melalui E-COMMERCE”.

Sriyana, J. (2010). Strategi Pengembangan Usaha Kecil Dan Menengah (UMKM): Studi Kasus Di Kabupaten Bantul. Simposium Nasional 2010: Menuju Purworejo Dinamis Dan Kreatif (hal. 79-103). Purworejo.

Sugiyono. (2014). Metode Penelitian Kuantitatif Kualitatif dan R\&D. Bandung: Alfabeta.

Sukmadinata, N.S. (2011). Metode Penelitian Pendidikan. Bandung: Remaja Rosadakarya.

T. Prasetyo Hadi Atmoko. (2018). Journal of Indonesian Tourism, Hospitality and Recreation Volume 1, Nomor 2. "Strategi Pemasaran Untuk Meningkatkan Volume Penjualan di Cavinton Hotel Yogyakarta”.

Tjiptono, Chandra. (2012). Penerapan Strategik 
(Edisi 2). Yogyakarta: ANDI. Wijayanti, Titik. (2012). Marketing Plan! Perlukah? Jakarta: PT. Gramedia Pustaka Utama.

Zebua, Ade jermawinsyah. (2018). Analisis
Strategi Pemasaran Dalam Meningkatkan Volume Penjualan Pada Shopie Paris BC. Yenni Kecamatan Muara Bulian. Jurnal Ilmiah, 18 (2). 222-229. 